\title{
ATTITUDE-BEHAVIOUR DISCREPANCY AND COGNITIVE DISONANCE: TACTICS FOR ENHANCING COMPLIANCE IN PERSUASIVE DISCOURSE ${ }^{1}$
}

\author{
Antonio García Gómez ${ }^{2}$
}

\begin{abstract}
In this paper I take a conversation analytic approach to examining persuasive strategies for enhancing compliance in talk show interaction. Basing my analysis on the discursive analysis of transcriptions of verbal aggression taken from the former UK TV talk show "Kilroy", I argue that conflictual episodes must not be viewed as an expressive act which results from a temporary loss of self-control but instrumentally. The discussion focuses on how guests' persuasive strategies are based on their ability to find a balance between expressing their (violent) emotions and eliciting personal information from their opponents. Personal information disclosure is therefore key to allowing guests to build alignment and inducing compliance in talk show verbal conflict sequences.
\end{abstract}

Key words: Conversation analysis, persuasive strategies, verbal conflict, speech acts.

Resumen: Desde un enfoque pragmatico-discursivo, el presente estudio examina las estrategias persuasivas que facilitan la adhesion a un punto de vista concreto en talk shows. A partir del análisis de diferentes extractos extraídos del talk show británico Kilroy, se argumenta que los episodios de habla conflictiva no deben ser entendidos como un acto expresivo producto de una pérdida momentanea de autocontrol sino como un acto premeditado e instrumental. El análisis revela que las estrategias persuasivas que los invitados usan se basan en la habilidad de hallar un equilibrio entre la expresión de las emociones propias de un enfrentamiento verbal y la obtención de información personal por parte de sus oponentes. Es pues la manipulación de esta información frente a la audiencia la que permite a los invitados atraer a los demás a su punto de vista y hacer que la estrategia de persuasión sea efectiva.

Palabras clave: Análisis de la conversación, estrategias persuasivas, conflicto verbal, actos de habla.

\section{INTRODUCTION}

In the last twenty years, the reality television phenomenon has transformed the face of television in many countries. In Europe, for instance, the private domain has gradually invaded the public domain in an attempt to increase audience ratings Hutchby (1996b). Different television formats which go from docusoaps to the most blatant examples of the recently baptised voyeur television have occupied several prime-time hours every weekday (Gregori Signes 2000 and 2001). As García Gómez (2007) points out, the fact of including

\footnotetext{
Date of reception: February 2008.

Date of acceptance and final version: June 2008.

2 Assistant Lecturer, Departamento de Filología Moderna, Universidad de Alcalá de Henares; $\square$ antonio. garciag@uah.es.
} 
violence as part of the spectacle is one of the essential ingredients for the success of programmes such as Masters and Servants ${ }^{3}$ or Wife Swap. ${ }^{4}$ Interestingly and in spite of the severe criticisms these programmes have received, the truth is that the audience ratings do increase with violent programmes. Therefore, it will come as no surprise that every day television uses more and more violence to hook its audience.

In particular, a wide range of talk shows has occupied the place that traditional narratives (i.e. miniseries, sitcoms and movies of the week) used to have. These audience discussion programmes show the transformation of the private domain into one which "can be manipulated and incorporated as an essential element for the theatricalisation of the intimate experiences of anonymous people" (Terribas and Puig 2000).

Owing to the fact that the industrial dynamic of the mass media demands entertainment, ordinary citizens with no special talent or expertise are invited to hang out their dirty linen for all to see on television (Hutchby 1996a; Thornborrow, 2001a and 2001b; O'keeffe 2006). In the end, interaction in this type of programmes usually descends into personal insults and easily degenerates into violence (Myers 2001; Wood 2001). In this context, conflict and verbal aggressive behaviour occur naturally in the process of discussing personal topics (i.e. unfaithful partners who must answer the questions of women who have been cheated on in past relationships). Although presenters are supposed to do their best to solve conflict constructively, guests end up exchanging accusations, insults, challenges, and expressions of criticism.

It is true that the study conflict talk from a psychological stance has attracted the attention of scholars (Grimshaw 1990; Briggs, 1996; Vuchinich et al., 2002; Vuchinich 2003a and $2003 \mathrm{~b}$ ); however, the realm of mediating persuasion, conflict managament and resolution in television shows has not been studied as extensively (for exceptions, see Gregori Signes 2000; García Gómez 2000, 2005, 2007 2008a and 2008b; Dickerson 2001; Lorenzo-Dus 2008), and this constitutes a gap in the current research on the literature. Therefore, the current research seeks to fill the empirical gap with findings from the discursive analysis of transcriptions of verbal aggression taken from former UK television talk show Kilroy.

This paper begins by establishing some basic principles for building the understanding of persuasive communication. The second part of the paper describes the corpus selection and the coding process. The third part focusses on the analysis of distinct persuasive tactics for enhancing compliance in talk show interaction. Finally, the main issues discussed in this paper are presented in section four. The transcription conventions are offered at the end of the paper.

\footnotetext{
In Masters and Servants two families move in together. Each family has got one week to enjoy being masters and one week to suffer being servants. It's a modern day, real life Upstairs Downstairs.

4 Two families, usually from vastly different social classes and lifestyles, swap wives/mothers (and sometimes husbands) for two weeks. During the first week, the new wife must adhere to the exact same rules and lifestyle of the wife she is replacing. Each wife leaves a house manual which explains her role in the family and the duties she holds. During the second week, the new wives are allowed to establish their own rules, and their new families must adhere to these new household rules.
} 


\section{REVIEW OF THE LITERATURE: PERSUASION, ATTITUDE AND BEHAVIOUR}

For a long time, social psychologists have devoted themselves to the study of successful and unsucessful persuasion; that is to say, what makes persuasive messages effective (Antaki 1994; Cotterill 2003). Studies of conflict talk and conflict management often use some kind of structured laboratory task which is designed in order to introduce verbal conflict behaviour. A particular group of people are typically brought into a laboratory and given an interaction task designed to produce conflict. Persuasion strategies, attitude and behaviour are then recorded and analysed (Putnam 2001; Vuchinich 2003a and 2003b).

Therefore, research in Social Psychology suggests that there are three variables in the context in which persuasion takes place: the source or the point of origin of a persuasive communication; the message or the kind of arguments involved and directed to an audience; and the audience or the intended target of a persuasive communication (see Hogg and Vaugham 2002). In addition to this, each of these variables interacts to either limit or increase the quality of persuasive arguments. More specificially, most influential social psychology studies suggest that there is evidence for a disconfirmation bias in argument evaluation (Edwards and Smith 1996). In other words, those arguments which contradict our own prior beliefs are usually weighed more carefully, have less credibility and are judged to be significantly less attractive than those arguments which are in harmony with our prior beliefs (García Gómez 2002).

In the lat ten years, discursive psychology has called attention to the need to analyse the distinct linguistic strategies people use in order to throw further light on the matter (Potter and Wetherell 1987). As Holtgraves and Lasky (1999) argue, a message becomes less persuasive with a powerless linguistic style (i.e. hesitations, frequent hedges, etc.). Indebted to discursive psychology, the analysis of naturally occuring conflict talk and the use of persuasion strategies have aroused great interest among discursive psychologists and discourse analysts.

The present paper aims to argue that persuasive discourse in talk show interaction correlates with anger expression. More precisely, I suggest that conflictual episodes must not be viewed as an expressive act which results from a temporary loss of self-control but instrumentally (i.e. as a tactic for enhancing compliance). As will be shown in section 3, guests' persuasive strategies are based on their ability to find a balance between expressing their (violent) emotions and eliciting personal information from their opponents. In a talk show conflictual episode, personal information disclosure is key to allowing guests to make their opponents see the wrongness of their (social) behaviour and/or point of view and the need to vary their stance on the topic under discussion.

\section{CORPUS SELECTION AND CODING PROCESS}

The sample of data is based on the video-tape recording and transcription of one of the most popular talk shows on British Television: Kilroy. The total number of programmes is fifteen and together they add up to around 180,000 words. The final corpus contained 89,937 annotated utterances from fifteen programmes that were highly confrontational. Following García Gómez' (2007 and in press) conversational analysis of talk show conflict talk, every 
utterance has been coded for its pragmatic meaning. Table 1 shows the taxonomy of speech acts found in the corpus and the frequence of each pragmatic meaning of utterances:

\begin{tabular}{|l|l|l|}
\hline Taxonomy of Speech Acts in conflictual episodes & Instances & Percentage \\
\hline Elicit: asking for information & 12,943 & $14.3911 \%$ \\
\hline Elicit: commitment to a future course of action & 7,539 & $8.3825 \%$ \\
\hline Elicit: agreement with own point of view & 1,297 & $1.4421 \%$ \\
\hline Elicit: clarification of opponents' point of view & 5,274 & $5.8663 \%$ \\
\hline Elicit: confirmation of opponent's point of view & 3,992 & $4.4386 \%$ \\
\hline $\begin{array}{l}\text { Elicit: commitment to course of action due to agreement with } \\
\text { speaker's point of view }\end{array}$ & 3.267 & $3.6325 \%$ \\
\hline Directive: imposition of a course of action on the opponent & 5,498 & $6.1131 \%$ \\
\hline $\begin{array}{l}\text { Directive: suggestion of a course of action for the opponents' ben- } \\
\text { efit }\end{array}$ & 6,569 & $7.3040 \%$ \\
\hline Directive: threat directed to the opponent & 9,246 & $10.2805 \%$ \\
\hline Directive: warning directed to the opponent & 5,398 & $6.0019 \%$ \\
\hline Informative: direct positive self-evaluation & 2,576 & $2.8642 \%$ \\
\hline Informative: indirect positive self-evaluation & 4,586 & $5.0991 \%$ \\
\hline Informative: direct negative self-evaluation & 1,395 & $1.5510 \%$ \\
\hline Informative: indirect negative self-evaluation & 1,004 & $1.1163 \%$ \\
\hline Informative: direct positive evaluation of the opponent & 2,678 & $2.9776 \%$ \\
\hline Informative: indirect positive evaluation of the opponent & 1,837 & $2.0425 \%$ \\
\hline Informative: direct negative evaluation of the opponent & 12,295 & $13.6706 \%$ \\
\hline Informative: indirect negative evaluation of the opponent & 3,569 & $3.9683 \%$ \\
\hline Total & 89,937 & $100 \%$ \\
\hline
\end{tabular}

Table 1. Adapted from García Gómez' (2007) Taxonomy of Speech Acts in talk show verbal conflict sequences.

\section{SELF-DISCLOSURE AND PERSUASIVE STRATEGIES IN TALK SHOW CONFLICT TALK}

We all know that calm intellectual discourse is not welcome to most talk show viewers (Thornborrow 2007). A plethora of emotions is triggered off by ordinary and seemingly trivial events which eventually cause a conflictual episode. Therefore, emotions and conflict are two of the critical ingredients of the talk show recipe; that is to say, the success of contemporary talk shows goes hand in hand with the amount of conflictual episodes they can offer to their home audience (García Gómez 2007 and 2008a). As Fischoff's points out (1995), "what this home audience finds so irresistible is the daily tumultuous dramas of guests enacting their lives, baring their wounds, divulging the crimes of their hearts and their loins, the predictable unpredictability of these dirty linen flauntings."

Therefore, self-disclosure in talk show interaction is an important determinant of persuasion. It is well known that people share more intimate topics with a close friend than with a casual acquaintance or a stranger (Altman and Taylor 1973). However, disclosing 
personal information and being sensitive and responsible to guests' disclosures are central processes in the development of conflict talk in general and the effectiveness of persuasive strategies in particular. Given that there is a tenuous interpersonal connection among the guests, the formal feature of the sample chosen for analysis may be defined as one adopting complimentary roles of equal/ equal; that is to say, guests' subject position (Fairclough 1989 ) is supposed to be set up on an equal status basis. Thus, no restriction in the guests' participation is expected -in terms of the parameter of power- and consequently the analysis will reflect without any restriction, the distinct linguistic resources that participants may take advantage in order to impose on the other and gain leadership.

\subsection{Building alignment in verbal conflict sequences: persuasive tactics for enhancing compliance}

As García Gómez (2008a) suggests, the persuasion complex itself, at the centre of the interaction, is made up of elicitations, directives and informatives of various kinds. For current purposes, I will concentrate my attention on the illocutionary persuasive intentions behind the use of elicitations and informatives. Detailed analysis of elicitations and informatives in the data suggest that they are powerful linguistic devices guests use, on the one hand, to facilitate the sharing of intimate information and feeling with other guests and, on the other hand, to persuade their opponents' by putting them in a situation where they cannot deny the veracity of the speaker's utterance (García Gómez, in press).

Inspection of the corpus shows that there are two techniques for inducing compliance in talk show verbal conflict sequences:

a) Ingratiation or Complimentary Other Enhancement. This tactic comes down to flattery. One guest focuses and exaggerates the positive side and ignores the negative side. In doing so, the ingratiatior communicates the idea that he or she thinks highly of the opponent (See Hogg and Vaughan 2002). This persuasive strategy correlates with Brown and Levinson's (1987) positive politeness strategies in so far as guests attempt to influence the opponents by agreeing with them and getting to like them.

b) Multiple requests. These are tactics for gaining compliance which use a two-step procedure: the first request functions as a set-up for the second real request (Hogg and Vaughan 2002). Out of the classic realisations, ${ }^{5}$ the foot-in-the-door tactic is the most recurrent persuasive strategy found in the data. Guests try to gain compliance by preceding the focal request by smaller requests which are less face threatening and, therefore, is bound to be accepted. Here I argue that these smaller requests can be understood as a mechanism of social control that is inspired by establishing negative opinions about the other group members. In doing so, guests attempt to legitimate

In the literature, there are three classic techniques for inducing compliance: a) the foot-in-the-door (FID) is a multiple request technique which aims to gain compliance, in which the focal request is preceded by a smaller request that is bound to be accepted; b) the door-in-the-face (DIF) presents a large request that is bound to be refused and then the focal request; and c) the low-balling technique for inducing compliance in which a person who agrees to a request can feel committed even after finding that there is a hidden cost. For further details see Hogg and Vaughan (2002). 
their positions against their opponents and vary the equal status distribution among participants.

Detailed analysis of these smaller requests or elicitations reveal that the informational content is the cumulative expression of the speaker's attitude and negative evaluations against his/her opponent (García Gómez 2000). Furthermore, the success of this persuasive strategy is based on the fact that the attitudinal colouring of these particular requests include an implicit social evaluation of the opponent's point of view and attitude. In other words, these smaller resquests or elicitations enable guests to control the topic of discourse and allow them to manipulate their opponents by forcing them to disclose personal information that, far from convincing other guests, ends up damaging their own face (Brown and Levinson 1987). Table 2 shows the distribution of speech acts in building alignment in talk show verbal conflict sequences:

\begin{tabular}{|c|l|l|l|}
\hline Distribution of speech acts in corpus & Ratio & $\begin{array}{l}\text { Distribution of speech acts in } \\
\text { corpus }\end{array}$ & Ratio \\
\hline Elicit (1): asking for information & 3.7 & $\begin{array}{l}\text { Directive (10): warning directed } \\
\text { to the opponent }\end{array}$ & 0.9 \\
\hline $\begin{array}{c}\text { Elicit (2): commitment to a future course } \\
\text { of action }\end{array}$ & 0.5 & $\begin{array}{l}\text { Informative (11): direct positive } \\
\text { self-evaluation }\end{array}$ & 10.4 \\
\hline $\begin{array}{c}\text { Elicit (3): agreement with own point of } \\
\text { view }\end{array}$ & 5.8 & $\begin{array}{l}\text { Informative (12): indirect posi- } \\
\text { tive self-evaluation }\end{array}$ & 17.6 \\
\hline $\begin{array}{c}\text { Elicit (4): clarification of opponents' } \\
\text { point of view }\end{array}$ & 4.8 & $\begin{array}{l}\text { Informative (13): direct negative } \\
\text { self-evaluation }\end{array}$ & 11.9 \\
\hline $\begin{array}{c}\text { Elicit (5): confirmation of opponent's } \\
\text { point of view }\end{array}$ & 4.3 & $\begin{array}{l}\text { Informative (14): indirect nega- } \\
\text { tive self-evaluation }\end{array}$ & 7.2 \\
\hline $\begin{array}{c}\text { Elicit (6): commitment to course of } \\
\text { action due to agreement with } \\
\text { speaker's point of view }\end{array}$ & 2.3 & $\begin{array}{l}\text { Informative (15): direct positive } \\
\text { evaluation of the opponent }\end{array}$ & 4.4 \\
\hline $\begin{array}{c}\text { Directive (7): imposition of a course of } \\
\text { action on the opponent }\end{array}$ & 0.7 & $\begin{array}{l}\text { Informative (16): indirect posi- } \\
\text { tive evaluation of the opponent }\end{array}$ & 3.6 \\
\hline $\begin{array}{c}\text { Directive (8): suggestion of a course of } \\
\text { action for the opponents' benefit }\end{array}$ & 4.7 & $\begin{array}{l}\text { Informative (17): direct negative } \\
\text { evaluation of the opponent }\end{array}$ & 12.9 \\
\hline $\begin{array}{c}\text { Directive (9): threat directed to the op- } \\
\text { ponent }\end{array}$ & 1.6 & $\begin{array}{l}\text { Informative (18): indirect nega- } \\
\text { tive evaluation of the opponent }\end{array}$ & 4.7 \\
\hline & Total & 100 \\
\hline
\end{tabular}

Table 2. Distribution of Speech Acts in building alignment: Ingratiation and multiple-requests in talk show verbal conflict sequences.

In extract 1, W1 uses a multiple-request technique to gain compliance and make M2 see the wrongness of what he is doing to his family. Linguistically speaking, this strategy shows a disposition toward negotiating two opposing realities (Shotter 1993). Due to this process of negotiation, guests mainly rely on elicitations and informatives that express varying degrees of adhesion to their own point of view (García Gómez 2008a). 


\section{Extract 1. Standing by an alcoholic partner}

\begin{tabular}{|c|c|c|}
\hline 102 & W1 & $\begin{array}{l}\text { You've just said (.) you never had a child with someone you (.) didn’t feel } \\
\text { is a good father (.) we all start off in a relationship with the very best intent } \\
\text { (.) no one can never see into the future (.) I agree with you (.) can I ask you } \\
\text { something } \uparrow\end{array}$ \\
\hline 103 & M2 & Yeah \\
\hline 104 & W1 & are you happy in your life $\uparrow$ \\
\hline 105 & M2 & yeah \\
\hline 106 & W1 & do you know there are many people that can help $\uparrow$ \\
\hline 107 & M2 & help me $\uparrow$ \\
\hline 108 & W1 & your wife says you're ill= \\
\hline 109 & M2 & $=$ don't think so \\
\hline 110 & W1 & $\begin{array}{l}\text { don't be ashamed (.) there are many people like you (.) a friend of mine has a } \\
\text { drinking problem as well (.) can I ask you when you started drinking } \uparrow\end{array}$ \\
\hline 111 & M2 & I'm a social drinker= \\
\hline 112 & W1 & $\begin{array}{l}\text { =yeah (.) but do you remember }(.) \text { when you actually started drinking too } \\
\text { much } \uparrow\end{array}$ \\
\hline 113 & M2 & never drank too much (.) I am a social ]drinker \\
\hline 114 & W1 & ]what time do your need your first drink $\uparrow$ \\
\hline 115 & M2 & don't know \\
\hline 116 & W1 & have you ever passed out before 10:00 am $\uparrow$ \\
\hline 117 & M2 & a couple of times (.) perhaps \\
\hline 118 & W1 & don’t you think it's pretty easy to see you have a drinking problem $\uparrow$ \\
\hline 119 & M2 & never thought about it seriously \\
\hline 120 & W1 & are you sure $\uparrow$ \\
\hline 121 & M2 & Yeah \\
\hline 122 & W1 & are YOU sure $\uparrow$ \\
\hline 123 & M2 & I said 'yes' \\
\hline 124 & W1 & $\begin{array}{l}\text { I'm very sorry about you (.) Emma ((his wife) })(.) \text { cause I must say to myself } \\
\text { that (.) I would never ever have a child by someone like you (.) no disrespect } \\
\text { (.) because I don't know you] }\end{array}$ \\
\hline 125 & W3 & $\begin{array}{l}\text { ]but this man is so nice (.) he's so kind when he is not drinking }(.) \text { he is great } \\
\text { with his son (.) unfortunately he has to see his son (.) when his mother says } \\
\text { (.) because I can't trust him (.) because of his problem (.) apart from that (.) } \\
\text { everyone will tell you (.) he is such a good ]man }\end{array}$ \\
\hline 126 & W1 & $\begin{array}{l}\text { JI don't see how you can defend him (.) I don't see how you can defend him } \\
\text { (.) he left you with the child after promising (.) you've got all the fertility } \\
\text { and everything (.) still he left you with the child if he was a good father }(.) \\
\text { he would be a father all the time (.) a father is not a two hour thing (.) but a } \\
\text { twenty-four hour thing (.) you do have a drinking problem }(.) \text { you can deny } \\
\text { it if you want but (.) you will not make the problem go away (.) you should } \\
\text { stop downing the bottle (.) sort out your priorities and stick to your family } \\
(\text { (applause)) }\end{array}$ \\
\hline 127 & M2 & in the back of my mind (.) I know you're right ((he bursts into tears)) \\
\hline
\end{tabular}


In this extract, W1 wants M2 to admit that he has a drinking problem in front of the audience. First, W1 uses elicitations as an ingratiation strategy (turns 102 and 104: "can I


asking for permission to elicit personal information and expresses her concern about how he feels. The remaining elicitations have to do with different aspects of M2's drinking problem and aim at gathering evidence to support her point (from turns 110 to 116: "can

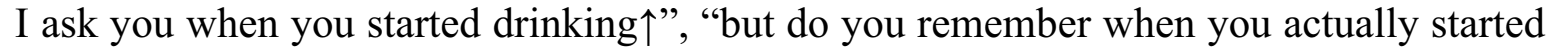

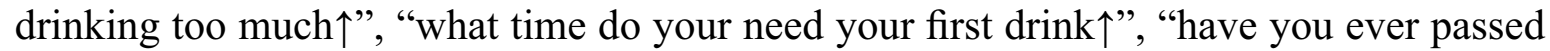
out before 10:00 am $\uparrow ")$. Here I suggest that these elicitations enhance compliance in so far as they are based on the notion that if $\mathrm{W} 1$ gets $\mathrm{M} 2$ to agree with the informational content of these elicitations, M2 will vary his stance of the topic; that is, he will eventually admit he has a drinking problem and need some medical treatment.

Given the fact that M2 challenges the illocutionary force of these elicitations, W1 ends up making explicit her persuasive intention in the following elicitation (turn 118: "Don't you think it's pretty easy to see you have a drinking problem $\uparrow$ ") which M2 challenges again. W1 does not accept the challenge and asks for confirmation twice (turns 120 and 122: "are

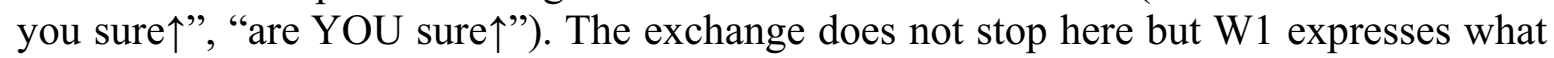
was self-evidently true in all the elicitations (turn 126: "you do have a drinking problem (.) you can deny it if you want but (.) you will not make the problem go away (.) you should stop downing the bottle (.) sort out your priorities and stick to your family").

Finally, M2 bursts into tears and admits he has a drinking problem (turn 126: "in the back of my mind (.) I know you're right.") The tactic is effective since it alters people's interpretation of situations that activate attitudes enhancing compliance. ${ }^{6}$ Needless to say, building alignment is a complex subtle phenomenon. The following section deals with a distinct tactic for enhancing compliance found in the data.

\subsection{Building alignment in verbal conflict sequences: From mutual aggression to mutual attraction}

Given the fact that most of the conflictive situations are the result of personal threats to interactants' own social identity (Edwards and Potter 1992; Edwards 2000). Inspection of the data reveals that guests also use elicitations and informatives in order to express varying degrees of adhesion to their own point of view (García Gómez 2000 and 2008a) and build alignment by moving from mutual aggression to mutual attaction. Here I argue that this strategy can be related to a persuasive tactic in so far as it shows a disposition toward negotiating two opposing realities.

The presence of elicitations and informatives can be related to ways of expressing the speaker's emotions which cover a range extending from fear of social criticism to aggression (García Gómez 2008b). Detailed analysis of elicitations and informatives in the data suggest that they are used in order to persuade the speakers' opponent by creating a friendly atmosphere. In other words, the succession of informatives and elicitations are narrations that move away from expressions of criticism to expressions of solidarity which aim to attract the verbal opponent to the speaker's point of view.

\footnotetext{
6 The literature on social influence defines compliance as "superficial, public and transitory change in behaviour and expressed attitudes in respose to requests, coercion or group pressure” (Hogg and Vaughan, 2002: 211).
} 
Inspection of the corpus shows that this tactic correlates with the reciprocity principle (Regan 1971). This principle is based on the social norm that we should treat others the way they treat us; that is to say, the tactic consists in creating a sense of obligation in someone. In talk show verbal conflict sequences, guests seem to induce reciprocity persuasion technique by sharing information. They tend to disclose some piece of personal information that the opponent does not have and would find valuable. Linguistically speaking, elicitations and informatives are connected with the reciprocity persuasion technique and are used to share a secret with those guests that held an opposing point of view.

The fact of sharing something about guests themselves is a form of giving and can create a strong desire on the part of the other guests to share information, open up, or give back in some other way (e.g. "let me share something with you, did you know I once...", "I've never told anyone but do you want me to tell you something about myself $\uparrow$ ). Therefore, the reciprocity principle gives the guest the ability to offer something very simple to his or her opponent(s) and quickly induce a desire to reciprocate. Inspection of the corpus shows that the kernel of this strategy lies in the fact that the opponent invalidates this other guest's attempt to induce compliance by distorting those negative social evaluations deriving from his or her own behaviour and trying to maintain the most favourable self-view through a process of social creativity.

Table 3 shows the distribution of speech acts in this persuasive strategy:

\begin{tabular}{|c|l|l|l|}
\hline Distribution of speech acts in corpus & Ratio & $\begin{array}{l}\text { Distribution of speech acts in } \\
\text { corpus }\end{array}$ & Ratio \\
\hline Elicit (1): asking for information & 9.2 & $\begin{array}{l}\text { Directive (10): warning directed } \\
\text { to the opponent }\end{array}$ & 1.2 \\
\hline $\begin{array}{c}\text { Elicit (2): commitment to a future course } \\
\text { of action }\end{array}$ & 6.9 & $\begin{array}{l}\text { Informative (11): direct positive } \\
\text { self-evaluation }\end{array}$ & 2.7 \\
\hline $\begin{array}{c}\text { Elicit (3): agreement with own point of } \\
\text { view }\end{array}$ & 9.1 & $\begin{array}{l}\text { Informative (12): indirect posi- } \\
\text { tive self-evaluation }\end{array}$ & 14.6 \\
\hline $\begin{array}{c}\text { Elicit (4): clarification of opponents' } \\
\text { point of view }\end{array}$ & 3.5 & $\begin{array}{l}\text { Informative (13): direct negative } \\
\text { self-evaluation }\end{array}$ & 1.3 \\
\hline $\begin{array}{c}\text { Elicit (5): confirmation of opponent's } \\
\text { point of view }\end{array}$ & 6.8 & $\begin{array}{l}\text { Informative (14): indirect nega- } \\
\text { tive self-evaluation }\end{array}$ & 0.7 \\
\hline $\begin{array}{c}\text { Elicit (6): commitment to course of } \\
\text { action due to agreement with } \\
\text { speaker's point of view }\end{array}$ & 6.2 & $\begin{array}{l}\text { Informative (15): direct positive } \\
\text { evaluation of the opponent }\end{array}$ & 5.2 \\
\hline $\begin{array}{c}\text { Directive (7): imposition of a course of } \\
\text { action on the opponent }\end{array}$ & 0.2 & $\begin{array}{l}\text { Informative (16): indirect posi- } \\
\text { tive evaluation of the opponent }\end{array}$ & 2.4 \\
\hline $\begin{array}{c}\text { Directive (8): suggestion of a course of } \\
\text { action for the opponents' benefit }\end{array}$ & 0.9 & $\begin{array}{l}\text { Informative (17): direct negative } \\
\text { evaluation of the opponent }\end{array}$ & 17.1 \\
\hline $\begin{array}{c}\text { Directive (9): threat directed to the op- } \\
\text { ponent }\end{array}$ & 0.3 & $\begin{array}{l}\text { Informative (18): indirect nega- } \\
\text { tive evaluation of the opponent }\end{array}$ & 11.7 \\
\hline & & Total & 100 \\
\hline
\end{tabular}

Table 3. Distribution of Speech Acts in building alignment: Reciprocity principle and social creativity in talk show verbal conflict sequences. 
As most of the conflictive situations are the result of personal threats to interactants' social identity, participants commonly attack each others' behaviours as a way to pave the way and create solidarity with the opponent (García Gómez 2007). Guests are unable to evaluate their social category membership positively (i.e. being an unfaithful husband; having problems with alcohol, etc.) and, therefore, the relative status of inferiority of the group constitutes a threat to the social identity of the individual group member (Hogg and Vaughan 2002). In these cases, if the presenter does not stop the conflictive episode, participants supplement the reciprocity persuasive strategy by attacking their own self-face behaviours in an attempt to exit from this negatively evaluated group. In my own terms, these participants attempt to restore their own self image by anticipating a counterargument to a potential face attack message from the opponents. Extract 2 illustrates this point, M1 combines the reciprocity principle with an attack to his own self-face behaviour:

\section{Extract 2: Left after a long marriage}

\begin{tabular}{|c|c|c|}
\hline 161 & W15 & can I just say? I'd like to share something about myself with you= \\
\hline 162 & M1 & $=$ I'd] \\
\hline 163 & W15 & $\begin{array}{l}\text { ]I do understand what you feel (.) not many people know (.) in a way I'm } \\
\text { ashamed of saying this on television= }\end{array}$ \\
\hline 164 & M1 & $=$ please do \\
\hline 165 & W15 & I fell attracted to another man (.) at first I thought it was love but] \\
\hline 166 & M1 & ]I really fell in love with] \\
\hline 167 & W15 & $\begin{array}{l}\text { ]I couldn't understand (.) I loved my husband to bits (.) but I fell attracted } \\
\text { to another man }\end{array}$ \\
\hline 168 & M1 & I couldn't help it (.) I] \\
\hline 169 & W15 & $\begin{array}{l}\text { JI have told nobody this before (.) I just wanted to share it with you (.) 'cos } \\
\text { after a couple of months I saw he was having an affair with somebody else } \\
\text { (.) I told my husband and he forgave me (.) we all have fell attracted to } \\
\text { somebody else but don't think you can fall in love with a complete stranger } \\
\text { (.) you're wrong (.) you think you're in love but you're not] }\end{array}$ \\
\hline 170 & W14 & $\begin{array}{l}\text { let me say (.) it's NOT RIGHT to carry on with the other person but (.) at } \\
\text { the same time (.) it seems to me the time you have had abroad (.) you had } \\
\text { very little contact with the wife at home (.) to know what was going on and } \\
\text { (.) you know (.) if you still felt something for her (.) I am sorry= }\end{array}$ \\
\hline 171 & W15 & $\begin{array}{l}=\text { I'm sorry for you (.) I'm sorry (.) you should have worked at your mar- } \\
\text { riage and sort it out (.) tried to find out what's gone wrong (.) you should } \\
\text { have communicated (.) more (.) erm (.) rekindled her love in some way }\end{array}$ \\
\hline 172 & M1 & $\begin{array}{l}\text { I loved her to pieces but there was NO WAY I could sort it ] out (.) I fell in } \\
\text { love with somebody else (.) I couldn't help it (.) I am just responsible for } \\
\text { my feelings (.) there was nothing I could do (.) I fell in love }\end{array}$ \\
\hline 173 & W15 & ]you should have divorced her then (.) I'm sorry but that's the way I think= \\
\hline 174 & M1 & $=$ it's better for the children to have two parents (.) right] \\
\hline 175 & W15 & $\begin{array}{l}\text { ]two parents that are not arguing (.) I don't think this is helpful to the child] } \\
\text { you should }\end{array}$ \\
\hline 176 & M1 & ]that's easier] \\
\hline 177 & W15 & $\begin{array}{l}\text { Jyou were selfish (.) you just satisfied your most basic instincts (.) you should } \\
\text { have divorced her (.) you should have been straightforward (.) that's what she } \\
\text { has done to you if she had fallen in love with another man }\end{array}$ \\
\hline
\end{tabular}


The statistical analysis of speech acts reflects that this persuasive strategy is mainly realised by means of informatives that aim at establishing three main facts that support the success of the strategy (García Gómez 2007):

1) Establishment of reciprocity between interactants. W15 aims to establish reciprocity by disclosing personal information about herself (turn 161: "I'd like to share something about myself with you"). She claims common ground by attending to M1's wants and exaggerating sympathy with M1 (turn 163: "I do understand what you feel (.) not many people know"; turn 169: "I have told nobody this before (.) I just wanted to share it with you."). Instead of criticising his behaviour, she first focuses on her own behaviour (turn 165: "I fell attracted to another man (.) at first I thought it was love but") and then she assesses inadequacy of her own performance (turn 169: "we all have fell attracted to somebody else but don't think you can fall in love with a complete stranger.") In doing so, she attempts to make him see that he is making the same mistake (turn 169: "you're wrong (.) you think you're in love but you're not").

2) Redeeming the past. In spite of W15's search for reciprocity, M1 is reluctant to admit he has a drinking problem in front of the audience. However, his actions are socially reprehensible and have already been evaluated negatively (i.e. responsible partners that are aware of their rights and duties in the marriage). M1 attempts to get rid of this negative social evaluation by associating all these negative actions with a past mistake that has nothing to do with the person he is at the present time (García Gómez 2007). On the one hand, M1 seeks agreement by claiming that he himself and his mother-in-law are cooperators as both of them love Rachel (turn 89 "I'm the right person (.) Margaret (.) I love your daughter to pieces"). On the other hand, there is a personal-centre switch as M1 narrates all the mistakes he made in the past as if he were W2. It is worth pointing out the repetitive use of the structure "I know" that precedes all the negative cricitisms, where M1 entails that W2's values are the same as M1's values at present. Here I argue that this presupposition manipulation fulfils a double function: claiming common ground and seeking agreement with the opponent as the strategy can be interpreted as an attempt to prove he really has changed (turn 89: "I know I made mistakes (.) I know I have fallen out no end of times (.) I know I have come back and said I HAVE CHANGED (.) but now I have (.) I have CHANGED (.) I know I was a bit of a boozer (.) I used to hang out with lads but ] I've changed").

3) Self-enhancement and social creativity. M1 tries to improve his self-esteem by promoting a friendly calm atmosphere (Turn 97: "now I am proud of the man I am"). In accordance with Augoustinos and Walker (1995: 110), analysis of the remaining turns reveals that an evaluation of one's self on both the personal and social levels will lead to an explicit social comparison with other social categories (Turn 97: "I am not better than anybody else but I am not the man you're saying"). In addition, the description of all the suffering he went through helps M1 exit from the negatively-evaluated in-group. The persuasive strategy consists of making W2 feel guilty and putting in her in a situation where forgiving is the appropriate social thing to do (turn 97: "I love her to pieces (.) just trust me (.) I've changed (.) people change (1.3) all I want is another chance (.) only lord knows how much I have 
suffered (.) I'm sorry for what I did (.) I cried my eyes out (.) nobody is an angel (.) now I only want another chance (.) please"). The effectiveness of the persuasive strategy lies, on the one hand, in the social pressure deriving from the situational context-TV interaction. On the other, the effectiveness has to do with the ability of M1 to put W2 in a corner and she eventually accepts the validity of M1's membership in the group as someone who made a mistake at some point of their life but now has changed (turn 99: "oh well (.) I must accept people may change (.) we all deserve a second chance in life (.) I will step back").

\section{CONCLUSIONS}

The current research has attempted to fill the empirical gap in the literature with findings from the discursive analysis of transcriptions of verbal aggression taken from the former UK TV Kilroy. More specifically, this paper analyses the correlation between persuasive discourse and verbal conflict sequences in talk show interaction. The pragmatic-discursive approach to the analysis of these verbal conflict sequences has made it possible to argue that conflictual episodes must not be viewed as an expressive act which results from a temporary loss of self-control but as a tactic for enhancing compliance.

Detailed analysis of the data has revealed that guests' persuasive strategies are based on their ability to find a balance between expressing their (violent) emotions and eliciting personal information from their opponents. In talk show interaction, there are three main techniques for building alignment and inducing compliance in verbal conflict sequences: a) ingratiation tactic, where guests focus and exaggerate the positive side and ignore the negative side; and b) multiple request tactic (foot-in-the-door tactic), where guests try to gain compliance by preceding the focal request by smaller requests which are less face threatening and, therefore, is bound to be accepted by other guests; c) reciprocity principle, self-enhancement and social creativity, where guests induce reciprocity persuasion technique by self-disclosing personal information with their verbal opponents. This process of self-disclosure is usually followed by a process of social creativity by means of which guest attempt to distort the negative social evaluations deriving from their own behaviour and maintain the most favourable self-view.

\section{REFERENCES}

Altman, I. and D. A. TAYlor, 1973. Social Penetration. New York: Holst, Rinehart, Winston.

ANTAKI, C. 1994. Explaining and Arguing: The Social Organisation of Accounts. London: Sage Publications.

Augoustinos, M. and I. Walker. 1995. Social Cognition. An Integrated Introduction. London: Sage publications.

Briggs, C.L., ed. 1996. Disorderly Discourse. Narrative, Conflict and Inequality. Oxford: Oxford University Press. 
Brown, P. and S. Levinson. 1987. Politeness. Cambridge: Cambridge University Press.

Cotterill, J. 2003. Language in Court: Power and Persuasion in the O. J. Simpson Trial. Palgrave: Basingstoke.

DiCKERSON, P. 2001. "Disputing with care: analyzing interviewees' treatment of interviewers' prior turns in televised political interviews". Discourse Studies 3: 203-222.

Edwards, D. and J. Potter. 1992. Discursive Psychology. London: Sage Publications.

EDWARDS, D. 2000. "Extreme case formulations: softeners, investment, and doing nonliteral". Research on Language and Social Interaction 33, 4: 347-373.

Edwards, K. and E.E. SMith. 1996. "A disconfirmation bias in the evaluation of arguments". Journal of Personality and Social Psychology 71: 5-24.

Fairclough, N. 1989. Language and Power. London: Longman.

Fischoff, S. 1995. "Confessions of a TV talk show shrink". Psychology Today 28, 5: $38-45$.

Foucault, M. 1972. The Archeology of Knowledge. New York: Pantheon.

García Gómez, A. 2000. "Discourse, politeness and gender roles: an exploratory investigation into British and Spanish Talk show verbal conflict". Estudios Ingleses de la Universidad Complutense 8: 97-125.

2002. "A Cognitive Approach to Topic Management in Verbal Duels on American Talkshows”. SELL 4: 145-170.

.2005. "The Social and Psychological Approach to Emotional and Conflict Expression”. Estudios de la Mujer: Discursos e identidades 5: 65-75.

.2007. Habla conflictiva como acción social. Discurso y Cognición. Oviedo: Septem Ediciones.

.2008. Assertive Behaviour and Gender Roles in Interpersonal Communication: A Contrastive Study. Madrid: Magister Editorial.

. (in press). La conversacionalización del discurso mediático en la televisión británica. Ideología, poder y cambio social. Oviedo: Septem Ediciones.

Gregori-Signes, C. 2000. "The tabloid Talkshow a quasi-conversational type of facteto-face interaction”. Pragmatics 10, 2: 195-213.

2001. "Opening Phase in American Tabloid Talkshows". La lingüística aplicada a finales del siglo XX. Ensayos y propuestas. Eds. I. de la CRUZ, C. SANtamaria, C. Tejedor y C. Valero. Servicio de Publicaciones de la Universidad de Alcalá. 555-562.

Grimshaw, A. D., ed. 1990. Conflict Talk: Sociolinguistic Investigations of Arguments in Conversations. Cambridge: Cambridge University Press.

Hogg, M.A. and G.M. Vaughan, 2002. Social Psychology. London: Prentice Hall. 
Holtgraves, T. and B. Lasky, 1999. "Linguistic power and persuasion". Journal of Language and Social Psychology 18: 196-205.

Hutchiy, I. 1996a. Confrontation Talk-Arguments, asymmetries, and Power on Talk Radio. Mahwah, NJ: Lawrence Erlbaum Associates.

.1996b. "Power in discourse: the case of arguments on a British talk radio show". Discourse and Society 7, 4: 481-497.

LoRENZO-Dus, N. 2008. "Real disorder in the court: an investigation of conflict talk in US television courtroom shows". Media, Culture and Society 30: 81-107.

Myers, G. 2001. 'I'm Out of It; You Guys Argue': Making an Issue of It on The Jerry Springer Show". Television Talk Shows. Discourse, Performance, Spectacle. Ed. A. Tolson. Mahwah, N.J.: Erlbaum. 173-192.

O’keEFFE, A. 2006. Investigating Media Discourse. London: Routledge.

Potter, J. and M. Wetherell. 1987. Discourse and Social Psychology. London: Sage

Putnan, S. 2001. Conflict in Language. London: Routledge

Shotter, J. 1993. Conversational Realities. Constructing Life Through Language. London: Sage Publications.

Terribas, M. and C. Puig. 2000. "The Theatricalisation of the Private Domain and the Hybridization of Television Genres. The Case of Big Brother". http://www.iuo.upf. es/formats/formats3/ter_a.htm (10 January 2008)

ThornBorrow, J. 2001a. "Authenticating talk: building public identities in audience participation broadcasting". Discourse Studies 3, 4: 459-479. 3, 4: 391-411.

. 2001b. "Authenticity, talk and mediated experience". Discourse Studies . 2007. "Narrative, opinion and situated argument in talk show discourse". Journal of Pragmatics 39, 8: 1436-1457.

Vuchinich, S. 2003a. "Social Problem Solving Training with Families". Social Problem Solving: Theory, Research and Training. Eds. E.C. ChAng, T.J. D'Zurilla and L.J. SAnNA. American Psychological Association: Washington, DC. 34-43. 2003b. "Family problem solving". The International Encyclopedia of Marriage and Family Relationships. Ed. J. PonzeTti. Macmillan Reference USA.: NY. 57-74.

Vuchinich, S., R. Ozretich, C. Pratt, and B. Kneedler. 2002. "Problem-Solving Communication in Foster Families and Birthfamilies". Child Welfare 81: 571-595.

Wood, H. 2001. 'No, YOU Rioted!': The Pursuit of Conflict in the Management of "Lay" and "Expert" Discourses on Kilroy". Television Talk Shows. Discourse, Performance, Spectacle. Ed. A. Tolson. Mahwah, N.J.: Erlbaum. 65-88. 


\section{Transcription conventions}

The following conventions were developed by Gail Jefferson:

\begin{tabular}{|l|l|}
\hline[] & $\begin{array}{l}\text { Square brackets mark the start and end of overlapping speech. Position them in } \\
\text { alignment where the overlap occurs }\end{array}$ \\
\hline$\uparrow \downarrow$ & $\begin{array}{l}\text { Vertical arrows precede marked pitch movement, over and above normal rhythms } \\
\text { of speech. They are for marked, hearably significant shifts -and even then, the } \\
\text { other symbols (full stops, commas, question marks) mop up most of that. Like } \\
\text { with all these symbols, the aim is to capture interactionally significant features, } \\
\text { hearable as such to an ordinary listener- especially deviations from a common } \\
\text { sense notion of "neutral", which admittedly has not been well defined }\end{array}$ \\
\hline CAPITALS & $\begin{array}{l}\text { Capitals mark speech that is obviously louder than surrounding speech (often oc- } \\
\text { curs when speakers are hearably competing for the floor, raised volume rather than } \\
\text { doing contrastive emphasis) }\end{array}$ \\
\hline$(0.4)$ & $\begin{array}{l}\text { Numbers in round brackets measure pauses in seconds (in this case, 4 tenths of a } \\
\text { second). Place on new line if not assigned to a speaker }\end{array}$ \\
\hline$()$. & A micropause, hearable but too short to measure \\
\hline$(($ text)) & Additional comments from the transcriber, e.g. context or intonation \\
\hline $\begin{array}{l}\text { s } \mathrm{h} \\
\text { wa::nted }\end{array}$ & $\begin{array}{l}\text { Colons show degrees of elongation of the prior sound; the more colons, the more } \\
\text { elongation }\end{array}$ \\
\hline Solid.= & "Equals" signs mark the immediate "latching" of \\
\hline$=$ We had & $\begin{array}{l}\text { successive talk, whether of one or more speakers, with no interval. Also used as } \\
\text { below (lines 3-5), where an unbroken turn has been split between two lines to ac- } \\
\text { commodate another speaker on the transcript page }\end{array}$ \\
\hline
\end{tabular}

